\title{
Comparing variations of peak expiratory flow among healthy adults from the Kuyavia-Pomeranian and Lublin districts of Poland
}

\author{
Maciej R. Składanowski ${ }^{1}$, Paweł Jarosz ${ }^{2}$, Barbara Mackiewicz ${ }^{2}$
}

\begin{abstract}
${ }^{1}$ Department of Psychiatric Nursing, Medical University of Lublin, Lublin, Poland 2Department of Pneumonology, Oncology and Allergology, Medical University of Lublin, Lublin, Poland
\end{abstract}

Submitted: 26 June 2018

Accepted: 28 December 2018

Arch Med Sci Civil Dis 2019; 4: e1-e6

DOI: https://doi.org/10.5114/amscd.2019.81666

Copyright @ 2019 Termedia \& Banach

\begin{abstract}
Introduction: Peak expiratory flow (PEF), a measure of lung function, was first described by Hadorn in 1942. The definition of PEF, written by the European Respiratory Society, states that it is the maximum flow achieved during the expiration phase, delivered with maximal force, starting from the maximum level of lung inflation. The aim of this study was to evaluate the variations of PEF associated with height, age, body surface area, place of residence and environmental factors among healthy adults in an urban setting in Poland.

Material and methods: The study comprised 88 healthy, non-smoking subjects: 30 females and 58 males, aged 20-80 years. Epidemiological and demographic data were collected from each participant, as well as information on symptoms and the occurrence of lung diseases. Only healthy subjects were selected for analysis. Participants completed spirometry testing; physical parameters were measured, and appropriate additional data obtained. Results: Among the study group of 88 participants (30 females and 58 males), peak expiratory flow rate was negatively correlated with age $(p=0.000001)$, and positively correlated with height and body surface area (both $p<0.000001$ ). There was a significant negative correlation between PEF and longitudinal environmental factors such as different particulate matter levels $(p=0.0007)$ present at the place of residence.

Conclusions: Peak expiratory flow changes are present in a healthy adult population. Place of residence and environmental factors influence the results of spirometry tests.
\end{abstract}

Key words: pollution, spirometry, environment, particulate matter.

\section{Introduction}

Spirometry testing is an important tool to aid the diagnosing and monitoring of respiratory diseases. It can assist in obtaining crucial information on the small and large airways, the parenchyma, as well as on pulmonary capillary bearing, its size and integrity. Pulmonary function tests (PFTs) are used to assess lung function. The main assumption of forceful expiration is clearly explained to each participant who performs an inspiration, which is required to acquire maximum lung volume; the participants then quickly and forcefully exhale to remove as much air from the lungs as possible [1, 2].

\author{
Corresponding author: \\ Maciej R. Składanowski MD \\ Department \\ of Psychiatric Nursing \\ Medical University \\ of Lublin \\ 18 Szkolna St \\ 20-124 Lublin, Poland \\ Phone: +48 693331020 \\ E-mail: macsklad@wp.pl
}


Peak expiratory flow rate (PEFR), which is a measure of lung function, was first described by Hadorn in 1942 and then accepted in 1949 as a parameter of spirometry [3]. The definition of PEFR written by the European Respiratory Society concludes that it is the maximum flow achieved during the expiration phase, delivered with maximal force, starting from the lung inflation level at its maximum. This occurs at approximately $100 \mathrm{~ms}$ from the start of a forced expiration and then peaks for $10 \mathrm{~ms}$. It is commonly used to monitor the progress of the disease and outcome of the treatment applied $[4,5]$. In the elderly, correlations are also found between peak expiratory flow (PEF) and different measures of physical and cognitive function [6]. The PEFR has also been known to predict the survival of older adults in selected populations [7-9] or participants with diabetes [10].

Peak expiratory flow is related to such factors as age, weight, height, race, and gender [11-13], and is also affected by altitude [14, 15], exercises $[16,17]$, parental smoking [18], the seasons and viral infections [19]. The purpose of this study was to evaluate the variations of PEF associated with such different factors as height, age, body surface area (BSA), place of residence and environmental factors among healthy adults in an urban setting.

\section{Material and methods}

The study comprised 88 healthy, non-smoking subjects, 30 females and 58 males, aged 20-80 years, resident in the Kuyavia-Pomeranian and Lublin districts of Poland, who participated in free screening tests in 2013-2015. Epidemiological and demographic data were collected from each participant, as well as information on symptoms and the occurrence of lung diseases. Exclusion criteria were: use of substances which could affect the respiratory system, chronic respiratory diseases, symptoms that could indicate undiagnosed pulmonary disease, and the occurrence of absolute or relative contraindications for spirometry. Participants completed spirometry tests; physical parameters such as weight and height were measured; additional data were obtained as required. All participants were Caucasians and written consent for participation in the tests was given individually by each participant. The approval of the competent Bioethics Committee for conducting the study was obtained.

Participants were told not to smoke, eat or exercise for at least $2 \mathrm{~h}$ prior to the test, as well as not to imbibe alcohol on the day of the test. Gender, age, height and weight were obtained from each participant. In addition, information about pulmonary diseases, symptoms that might indicate an undiagnosed illness (shortness of breath, chronic cough and its character, swelling, presence of sputum and its nature, change of appetite or body weight in the last year), as well as information on any comorbidities, was collected. Heart rate and blood pressure were measured.

Spirometry tests were performed in accordance with the recommendations of the European Respiratory Society (ERS), the American Thoracic Society (ATS) and the Polish Lung Disease Committee (PTChP) $[1,2,20]$. First, each participant took a few quiet breaths while seated in an upright position, then performed a maximum inspiration, followed by a slow, deep exhalation. In the next phase of the study, each participant performed a dynamic, forceful exhalation after a maximum inspiration. According to the instructions of the measuring apparatus and on a signal from the spirometer, the participant performed an inspiration after a forced expiration lasting at least for $6 \mathrm{~s}$. Individual breathing maneuvers were performed to obtain at least three reproducible, technically correct records, of which at least two forced expiratory curves differed in forced vital capacity (FVC) and forced expiratory volume $\left(\mathrm{FEV}_{1}\right)$ of less than $150 \mathrm{ml}[21,22]$. The spirometer also controlled the correctness of the test by checking the start of the exhalation phase (time from the start of the manoeuver to achieving peak flow (PEF) $<300 \mathrm{~ms}$, back-extrapolated volume of FVC $<5 \%$ or $100 \mathrm{ml}$ ), and morphology of the respiratory curve. For further analysis, the best criteria meeting the maneuvers were chosen, i.e. those obtaining the highest scores. Reproducibility was evaluated with a fivepoint scale A-F, although only A and B grade tests were included in the analysis. Body surface area was calculated according to the Du Bois formula [23]: $0.007184 \times$ weight $^{0.425} \times$ height $^{0.725}$.

\section{Statistical analysis}

For analysis of the data obtained, a number of statistical methods were used due to the diversity of variables taken into account (both qualitative and quantitative), as well as the assumptions of the statistical tests. In accordance with the principles of selection of statistical tests, in order to verify the normality of the quantitative variables, the Kolmogorov-Smirnov, Lilliefors and Shapiro-Wilk tests were performed. Levene's test was used to examine the homogeneity of variance. Analyses of variance (ANOVA), with appropriate post-hoc Tukey tests, were used where available. To assess the differences between the average values of $k$ independent samples, the Kruskal-Wallis nonparametric test with appropriate post-hoc modifications was performed, if needed.

To evaluate the correlation between continuous variables, Spearman's R, Kendall's $\tau$ and $\gamma$ tests were used. For analysis of the significance of differences between groups, compared to the 
qualitative characteristics of the study population, Pearson's $\chi^{2}$, and for understanding the potential strength of this relationship, Kendall's $\tau$ and coefficient of contingency tests were applied.

\section{Results}

In the study group of 88 participants (30 females, 58 males), 42 were tested in the Kuyavia-Pomeranian District and 46 in the Lublin District. Mean \pm standard deviation (SD) age was $49 \pm 17.69$ years, with the majority in the 20-30 age group, followed by the 60-70 age group; mean height was $172 \pm 10.62 \mathrm{~cm}$, with the majority in the 160-180 cm group; mean weight was $80 \pm 16.17 \mathrm{~kg}$, the majority in the $80-90 \mathrm{~kg}$ group. Mean BSA was $1.93 \pm 0.23 \mathrm{~m}^{2}$; mean PEFR was $7.56 \pm 2.39 \mathrm{l} / \mathrm{min}$.

A negative correlation between PEFR and age (Spearman's $R-0.494 ; \gamma-0.348$; Kendall $\tau-$ $0.345 ; p=0.000001$ ), as well as a positive correlation between PEFR and height (Spearman's $R-$ $0.662 ; \gamma-0.500$; Kendall $\tau-0.490 ; p<0.000001$ ) was found, in line with expectations.

A positive correlation was found between PEFR and BSA (Spearman's $R-0.593 ; \gamma-0.421$; Kendall $\tau-0.421 ; p<0.000001$ ) (Figures $1-3$ ).

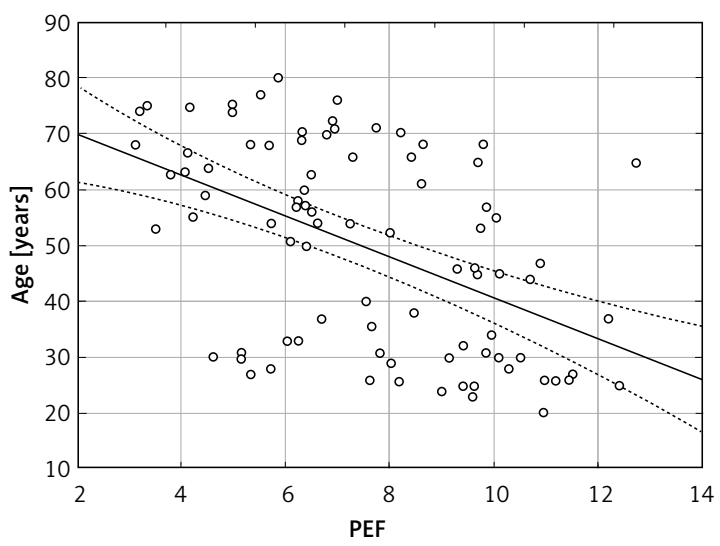

Figure 1. Peak expiratory flow (PEF) vs. age

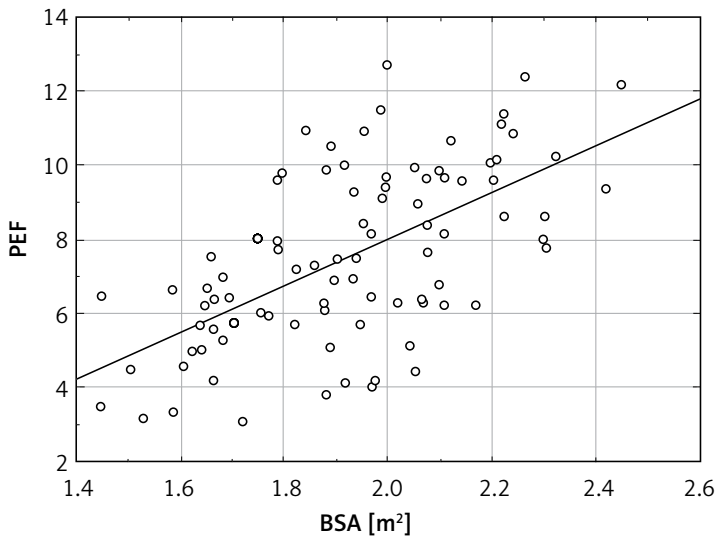

Figure 3. Peak expiratory flow (PEF) vs. body surface area (BSA)
There was also a major difference in spirometry test values between the populations studied in the Kuyavia-Pomeranian and Lublin districts. The population tested in the latter district had statistically significantly lower PEF values than those tested in the Kuyavia-Pomeranian District ( $p=$ 0.0007) (Figure 4).

In the Kuyavia-Pomeranian District, 24-hour and hourly concentrations of air pollution were obtained from a nearby air testing station. Unfortunately, no air testing stations were available in the proximity of the examination site in the Lublin District. Therefore, data were obtained for both districts from the General Inspectorate of Environmental Protection for the proper time of examination. It appeared that during the test dates there were differences concerning particulate matter volumes (Table I) [24, 25].

In the Lublin District, the amount of emitted dust particles increased by about $2.7 \%$ compared to the year 2014. At all measurement sites, the annual average permissible concentrations of $\mathrm{PM}_{10}$, i.e. $40 \mu \mathrm{g} / \mathrm{m}^{3}$, were met. It was found, however, that the allowable limit for $24 \mathrm{~h}$, i.e. $50 \mu \mathrm{g} / \mathrm{m}^{3}$, was exceeded. This means that each station had more than 35 days (up to 66 days) during which

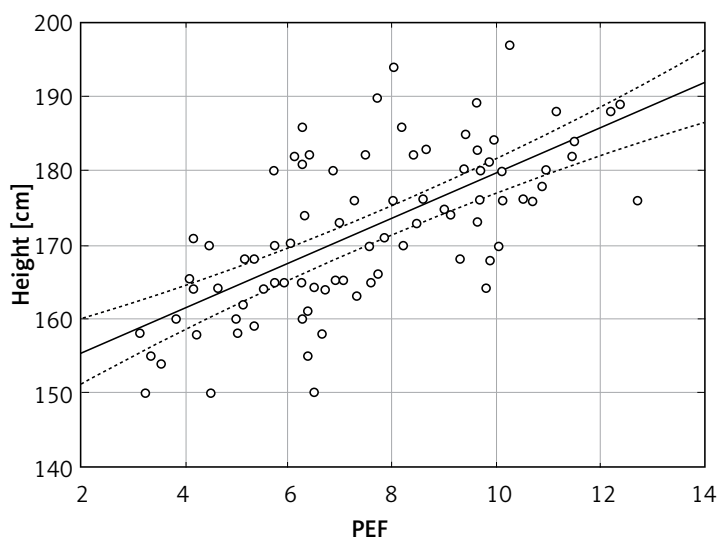

Figure 2. Peak expiratory flow (PEF) vs. height

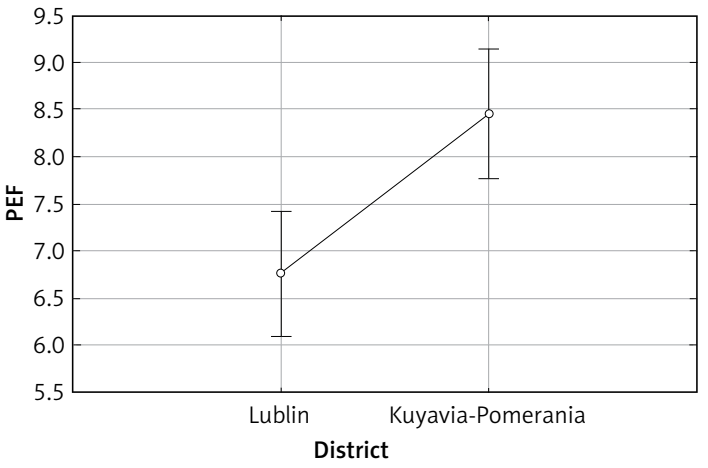

Current effect: $F(1,86)=12.379, p=0.0007$

Effective hypothesis decomposition

Vertical bars denote 0.95 confidence intervals

Figure 4. Peak expiratory flow (PEF) vs. districts 
Table I. Mean daily particulate matter concentrations measured by air test stations closest to examination sites $[24,25]$

\begin{tabular}{|c|c|c|c|c|}
\hline \multirow{2}{*}{$\begin{array}{l}\text { Districts } \\
\text { Kuyavia-Pomerania }\end{array}$} & \multicolumn{2}{|c|}{ Daily $\mathrm{PM}_{10}$ concentration } & \multicolumn{2}{|c|}{ Daily $\mathrm{PM}_{2.5}$ concentration } \\
\hline & First day & Second day & First day & Second day \\
\hline & 22.425 & 9.7 & 15.321 & 5.96 \\
\hline Lublin & \multicolumn{2}{|c|}{81.229} & \multicolumn{2}{|c|}{65.375} \\
\hline
\end{tabular}

Table II. Zone classes for examined districts during spirometry tests (combined data from 2013 and 2015) [26, 27]

\begin{tabular}{|lcccccccccccc|}
\hline District & $\mathrm{SO}_{2}$ & $\mathrm{NO}_{2}$ & $\mathrm{PM}_{10}$ & $\mathrm{~Pb}$ & $\mathrm{C}_{6} \mathrm{~h}_{6}$ & $\mathrm{CO}$ & $\mathrm{O}_{3}$ & $\mathrm{As}$ & $\mathrm{Cd}$ & $\mathrm{Ni}$ & $\mathrm{BaP}$ & $\mathrm{PM} \mathbf{2}_{2,5}$ \\
\hline Lublin & $\mathrm{A}$ & $\mathrm{A}$ & $\mathrm{C}$ & $\mathrm{A}$ & $\mathrm{A}$ & $\mathrm{A}$ & $\mathrm{A}$ & $\mathrm{A}$ & $\mathrm{A}$ & $\mathrm{A}$ & $\mathrm{C}$ & $\mathrm{C}$ \\
\hline $\begin{array}{l}\text { Kuyavia- } \\
\text { Pomerania }\end{array}$ & $\mathrm{A}$ & $\mathrm{A}$ & $\mathrm{C}$ & $\mathrm{A}$ & $\mathrm{A}$ & $\mathrm{A}$ & $\mathrm{A}$ & $\mathrm{A}$ & $\mathrm{A}$ & $\mathrm{A}$ & $\mathrm{C}$ & $\mathrm{A}$ \\
\hline
\end{tabular}

A - zone class for pollutants with concentrations below permissible or target levels. $C$ - zone class for pollutants with concentrations exceeding permissible or target levels.

concentrations were above $50 \mu \mathrm{g} / \mathrm{m}^{3}$. The mean concentrations for the year ranged from 29.2 to $36.4 \mu \mathrm{g} / \mathrm{m}^{3}$, achieving a mean value of $32.6 \mu \mathrm{g} / \mathrm{m}^{3}$. The highest 24-hour concentration was $187 \mu \mathrm{g} / \mathrm{m}^{3}$. High concentration values occurred during the heating period in each year.

$\mathrm{PM}_{2.5}$ air pollution was assessed on the basis of one criterion: the average concentration for the year. The mean concentrations for the year in the Lublin District ranged from $21.3-28.2 \mu \mathrm{g} / \mathrm{m}^{3}$ up to $141 \%$ of the target level of $20 \mu \mathrm{g} / \mathrm{m}^{3}$ and $112.8 \%$ of the permissible level of $25 \mu \mathrm{g} / \mathrm{m}^{3}$. Values exceeding the permissible level were recorded at more than half of the measurement stations. The percentage of $\mathrm{PM}_{2.5}$ dust in $\mathrm{PM}_{10}$ varied from $70 \%$ to $81 \%$ [26].

In the Kuyavia-Pomeranian District, for annual mean concentrations, the $\mathrm{PM}_{2.5}$ dust content in $\mathrm{PM}_{10}$ was $82.3 \%$, as in the previous year. The annual average for $\mathrm{PM}_{10}$ dust was lower than in the previous year and was $17.6 \mu \mathrm{g} / \mathrm{m}^{3}$, which constituted $44.0 \%$ of the permissible level. A lower frequency of $\mathrm{PM}_{10}$ exceeding the allowable limit for $24 \mathrm{~h}$ $\left(50 \mu \mathrm{g} / \mathrm{m}^{3}\right)$ was observed 7 times. The annual average for $\mathrm{PM}_{2.5}$ was $14.5 \mu \mathrm{g} / \mathrm{m}^{3}$, which was $58.0 \%$ of the target volume. Maximum concentrations of $\mathrm{PM}_{10}$ and $\mathrm{PM}_{2.5}$ were close to one another: $\mathrm{PM}_{10}$ recorded level - $78.7 \mathrm{\mu g} / \mathrm{m}^{3} ; \mathrm{PM}_{2.5}-77.7 \mathrm{\mu g} / \mathrm{m}^{3}$ [27] (Table II).

\section{Discussion}

The occurrence of a negative correlation between PEF values and age is consistent with previous reports $[28,29]$ and can be explained by the rigidity of the chest wall increasing with age, as well as by reduction of the elastic recoil of the lungs. The outcome is a reduction of spirometry values. Air trapping and hyperinflation lead to further increase in functional residual capacity (FRC) and residual volume (RV) [30-33]; premature closing of the distal alveoli takes place [32, 34]. With the increase of RV, a reduction of the diaphragm curvature occurs which, in turn, causes a diminution of strength of this muscle and further deterioration of airflow in the lungs. The efficiency of intercostal muscles also decreases [30, 32, 35].

A positive correlation between PEF values and height reflects the findings of different authors [36-38]. This can probably be explained by a greater chest size connected with greater lung volume in taller subjects, as well as the size of the airway passages or the increased expiratory muscle effort, positively related to an increase in participants' height $[39,40]$. A statistically significant, positive correlation between PEF and BSA was found, which is consistent with the results of other studies [37, 39].

The participants tested in the Kuyavia-Pomeranian District had statistically significantly higher values of PEF than those tested in the Lublin District. According to the General Inspectorate of Environmental Protection, emissions from low emitters of combustion products from domestic furnaces and local coal-fired boilers during the heating season have a significant impact on air quality in the Lublin District. The $\mathrm{PM}_{10}$ level has a decisive influence on air quality. This is due mainly to the use of hard coal for heating purposes, which results in an increase in the concentration of dust in the cold season. It is also worth bearing in mind that the share of $\mathrm{PM}_{2.5}$ dust in $\mathrm{PM}_{10}$ varied from $70 \%$ to $81 \%[26,41]$; this is also in line with the data from the Lublin District study time - February. In the Kuyavia-Pomeranian District the study was conducted in late June. The mean $\mathrm{PM}_{10}$ and $P M_{2.5}$ volumes were substantially higher in the Lublin District compared to the Kuyavia-Pomeranian District, including hourly, daily and yearly means at the time of the study [26, 27, 41].

Regarding the influence of particulate matter concentrations on PEF, van der Zee et al. found 
that participants with asthma were considerably more susceptible to particulate air matter [42]. This was in line with the work of Yamazaki et al. [43]. A decrease in spirometric values among healthy women living in areas with increased volumes of $\mathrm{PM}_{2.5}$ was confirmed by Kumar et al. [44]. Similar results were observed in the Lesser Poland region in a study undertaken by Mejza et al., which concerned a random population of that region, where coal or wood is used for heating and cooking [45].

In conclusion, PEF changes are also present in the healthy adult population, and are negatively correlated with age, and positively correlated with height and BSA.

Places of residence and environmental factors influence the results of spirometry testing, such as PEF. Further analyses are needed for a better understanding of the longitudinal environmental factors' influence on human health.

\section{Conflict of interest}

The authors declare no conflict of interest.

\section{References}

1. American Thoracic Society. Standarization of spirometry. Update. Am J Respir Crit Care Med 1995; 152: 1107-36.

2. Miller M, Hankinson J, Brusasco V, et al. Standardisation of spirometry. Eur Respir J 2005; 26: 319-38.

3. Jain SK, Kumar R, Sharma DA. Peak expiratory flow rates (PEFR) in healthy Indian adults: a statistical evaluation-I. Lung India 1983; 1: 88-91.

4. Quanjer PH, Lebowitz MD, Gregg I, Miller MR, Pedersen OF. Peak expiratory flow. Conclusion and recommendations of a working party of the European Respiratory Society. Eur Respir J Suppl 1997; 24: 2S-8S.

5. Pederson OF; The Peak Flow Working Group. Physiological determinants of peak expiratory flow. Eur Respir J Suppl 1997; 24: 11S-6S.

6. Cook NR, Albert MS, Berkman LF, Blazer D, Taylor JO, Hennekens $\mathrm{CH}$. Interrelationships of peak expiratory flow rate with physical and cognitive function in the elderly: MacArthur Foundation studies of aging. J Gerontol A Biol Sci Med Sci 1995; 50: M317-23.

7. Fragoso CA, Gahbauer EA, Van Ness PH, Concato J, Gill TM. Peak expiratory flow as a predictor of subsequent disability and death in community-living older persons. J Am Geriatr Soc 2008; 56: 1014-20.

8. Cook NR, Evans DA, Scherr PA, Speizer FE, Taylor JO, Hennekens $\mathrm{CH}$. Peak expiratory flow rate and 5-year mortality in an elderly population. Am J Epidemiol 1991; 133: 784-94.

9. Tilvis R, Valvanne J, Sairanen S, Sovijärvi A. Peak expiratory flow is a prognostic indicator in elderly people. BM 1997; 314: 605-6.

10. Klein BE, Moss SE, Klein R, Cruickshanks KJ. Peak expiratory flow rate: relationship to risk variables and mortality: the Wisconsin Epidemiologic Study of diabetic retinopathy. Diabetes Care 2001; 24: 1967-71.

11. Qureshi KA, Hassan G, Masoodi MA, Khan GQ. Peak expiratory flow rate among Gujjar and non-Gujjar population of Kashmir valley. JK Sci 2004; 6: 84-7.
12. Elebute EA, Femi-Pearse D. Peak flow rate in Nigeria: anthropometric determinants and usefulness in assessment of ventilator function. Thorax 1971; 26: 597-601.

13. Hankinson JL, Odencrantz JR, Fedan KB. Spirometric reference values from a sample of the general U.S. population. Am J Respir Crit Care Med 1999; 159: 179-87.

14. Gupta S, Mittal S, Kumar A, Singh KD. Peak expiratory flow rate of healthy school children living at high altitude. N Am J Med Sci 2013; 5: 422-6.

15. Thomas PS, Harding RM, Milledge JS. Peak expiratory flow at altitude. Thorax 1990; 45: 620-2.

16. Tsanakas JN, Milner RD, Bannister OM, Boon AW. Free running asthma screening test. Arch Dis Child 1988; 63: 261-5.

17. Frischer T, Kühr J, Meinert R, Karmaus W, Forster J, Urbanek R. Relation between response to exercise and diurnal variability of peak expiratory flow in primary school children. Thorax 1993; 48: 249-53.

18. Cook DG, Strachan DP. Parental smoking, bronchial reactivity and peak flow variability in children. Thorax 1998; 53: 295-301.

19. Olenec JP, Kim WK, Lee WM, et al. Weekly monitoring of children with asthma for infections and illness during common cold seasons. J Allergy Clin Immunol 2010; 125: 1001-6.

20. PTChP. Zalecenia Polskiego Towarzystwa Chorób Płuc dotyczące wykonywania badań spirometrycznych. Pneumonol Alergol Pol 2006; 74: 1-44.

21. Gondorowicz K, Siergiejko Z. Procedury wykonywania badań, akceptowalności i powtarzalności pomiarów. Pneumonol Alergol Pol Suppl 2006; 74: 17-20.

22. Ferguson GT, Enright PL, Buist AS, Higgins MW. Office spirometry for lung health assessment in adults. A consensus statement from the National Lung Health Education Program. Chest 2000; 117: 1146-61.

23. Du Bois D, Du Bois EF. A formula to estimate the approximate surface area if height and weight be known. Nutrition 1989; 5: 303-11.

24. Wojewódzki Inspektorat Ochrony Środowiska w Bydgoszczy. Pomiary automatyczne zanieczyszczeń powietrza w województwie kujawsko-pomorskim [Online]. Available: http://78.10.38.165/index.php?page=opis-stacji\&idstacji $=37$.

25. Wojewódzki Inspektorat Ochrony Środowiska w Lublinie. System monitoringu jakości powietrza [Online]. Available: http://envir.wios.lublin.pl/?page =opisy-stacji\&t=1\&site id $=2$.

26. Wojewódzki Inspektorat Ochrony Środowiska w Lublinie. Raport o stanie środowiska województwa lubelskiego w 2015 roku. Lublin: Biblioteka Monitoringu Środowiska, 2016.

27. Wojewódzki Inspektorat Ochrony Środowiska w Bydgoszczy, Raport o stanie środowiska województwa kujawsko-pomorskiego w 2013 roku, Bydgoszcz: Biblioteka Monitoringu Środowiska, 2014.

28. Gregg I, Nunn AJ. Peak expiratory flow in normal subjects. Br Med J 1973; 3: 282-4.

29. Woolcock AJ, Colman MH, Blackburn CR. Factors affecting normal values for ventilatory lung function. Am Rev Respir Dis 1972; 106: 692-709.

30. Meyer K. Aging. Proc Am Thorac Soc 2005; 2: 433-9.

31. Stanojevic S, Wade A, Stocks J, et al. Reference ranges for spirometry across all ages: a new approach. Am J Respir Crit Care Med 2008; 177: 253-60.

32. Janssens JP. Aging of the respiratory system: impact on pulmonary function tests and adaptation to exertion. Clin Chest Med 2005; 26: 469-84. 
33. Fletcher C, Peto R. The natural history of chronic airflow obstruction. BMJ 1977; 1: 1645-8.

34. Leblanc P, Ruff F, Milic-Emili J. Effects of age and body position on "airway closure" in man. J Appl Physiol 1970; 28: 448-51.

35. Polkey $\mathrm{MI}$, Hamnegård $\mathrm{CH}$, Hughes PD, Rafferty GF, Green $M$, Moxham J. Influence of acute lung volume change on contractile properties of human diaphragm. J Appl Physiol 1998; 85: 1322-8.

36. Elebute EA, Femi-Pearse D. Peak flow rate in Nigeria: anthropometric determinants and usefulness in assessment of ventilatory function. Thorax 1971; 26: 597-601.

37. Jain A, Singh M. Effect of occupational exposure to pollutants on peak expiratory flow rate of healthy non-smoking bus drivers in the age group of 20-55 years. J Clin Diagn Res 2012; 6: 176-9.

38. Sharma M, Sharma RB, Choudhary R. Peak expiratory flow rate in children of Western Rajasthan 7-14 years of age. Pak J Physiol 2012; 8: 45-8.

39. Jepegnanam V, Sulochana A, Swamy D, Rao VM. Peak expiratory flow rate in a random healthy adult population of Coimbatore. Indian J Physiol Pharmacol 1996; 40: 127-33.

40. Harpreet K, Jagseer S, Manisha M, Khushdeep S, Ruchika G. Variations in the peak expiratory flow rate with various factors in a population of healthy women of the Malwa Region of Punjab, India. J Clin Diagn Res 2013; 7: 1000-3.

41. Stan środowiska w Polsce. Sygnały 2016, Warsaw: Biblioteka Monitoringu Środowiska, 2017.

42. van der Zee S, Hoek G, Boezen HM, Schouten JP, van Wijnen JH, Brunekreef B. Acute effects of urban air pollution on respiratory health of children with and without chronic respiratory symptoms. Occup Environ Med December 1999; 56: 802-12.

43. Yamazaki S, Shima M, Ando M, Nitta $H$, Watanabe $H$ Nishimuta T. Effect of hourly concentration of particulate matter on peak expiratory flow in hospitalized children: a panel study. Environ Health 2011; 10: 15.

44. Kumar R, Singh K, Nagar S, et al. Pollutant levels at cooking place and their association with respiratory symptoms in women in a rural area of Delhi-NCR. Indian J Chest Dis Allied Sci 2015; 57: 225-31.

45. Mejza F, Nastatek P, Skucha W, Harat R, NiżankowskaMogilnicka E. Effects of biomass combustion and occupational exposures on lung function in random population sample of Malopolska inhabitants. Pneumonol Alergol Pol 2012; 80: 509-15. 